\title{
Rare spider species (Araneae) from the Giant Mountains and the Izera Mountains - new records for the fauna of Poland
}

\author{
Konrad WIŚNIEWSKI and Wanda WESOŁOWSKA \\ Department of Biodiversity and Evolutionary Taxonomy, Faculty of Biological Sciences, University of Wroctaw, \\ Przybyszewskiego 65, 51-148 Wrocław, Poland; e-mail: konwisniew@gmail.com
}

\begin{abstract}
We present data on four spider species (Araneae) new for the fauna of Poland. The spiders were found predominantly in the mires of the Giant Mountains and the Izera Mountains (the Western Sudetes). Some of these habitats are the transborder mires between Poland and the Czech Republic. The presented species are: Erigone cristatopalpus, Panamomops sulcifrons, Theridion boesenbergi, Gnaphosa lapponum. Each of these spiders is rare or lives in specific habitat.
\end{abstract}

Key words: new records, Erigone cristatopalpus, Gnaphosa lapponum, Panamomops sulcifrons, Theridion boesenbergi, the Western Sudetes

\section{INTRODUCTION}

Although the spider fauna of the Giant Mountains (=Karkonosze/Krkonoše) and the Izera Mountains (=Góry Izerskie/Jizerské hory) was studied by many authors (summarized by Woźny et al. 1988, Kůrka 1999, Tomasiewicz \& Woźny 2004, Kůrka \& Szymkowiak 2007), our knowledge on invertebrates of these mountain ranges is still incomplete. Consequently, a few rare spiders were recorded there in recent fifteen years, all of the listed species were new to the fauna of Poland. These were three Maro species (Linyphiidae), i.e. M. lehtineni Saaristo, 1971 (Wiśniewski \& Wesołowska 2015), M. lepidus Casemir, 1961 (Wiśniewski \& Wesołowska 2012), M. sublestus Falconer, 1915 (Szymkowiak 2004) and Iberina difficilis (Harm, 1966) from Hahniidae (Wiśniewski et al. 2013). In this article we present four other spider species from the region, which are new to the fauna of Poland.

\section{METHODS}

The records presented here are the result of the broad study of spider assemblages in different mires of the Giant Mountains and the Izera Mountains (the Western Sudetes), in the years 2010-2012. Pitfall traps and a sweep net were used as sampling methods. In 2010 and 2011 we investigated spiders from twenty one mires. In 2012 the research were continued in 5 mires and their nearest vicinity (a spruce forest, dwarf mountain pine and different grasslands). All records come from the territory of Poland and only the Polish national species list will be considered in the paper (Rozwałka \& Stańska 2008, Kupryjanowicz 2008). However, many spiders were found just by the national border, some of the mires mentioned here are located at the plateau of the Giant Mountains, in the territory of both countries. 


\section{RECORDED SPECIES}

Linyphiidae

\section{Erigone cristatopalpus Simon, 1884}

(Figs 1-6)

Material: Eastern Giant Mts. by the peak called Smogornia (PL)/Stříbrný hřbet (CZ), 5044'54"N, 1541'20"E, 1410 m a.s.l., pitfall traps, 2 males, 11-31 May 2011 and 11-31 May 2012; a transborder subalpine mire with a mosaic of habitats, i.e. raised and transition parts and dwarf mountain pine.

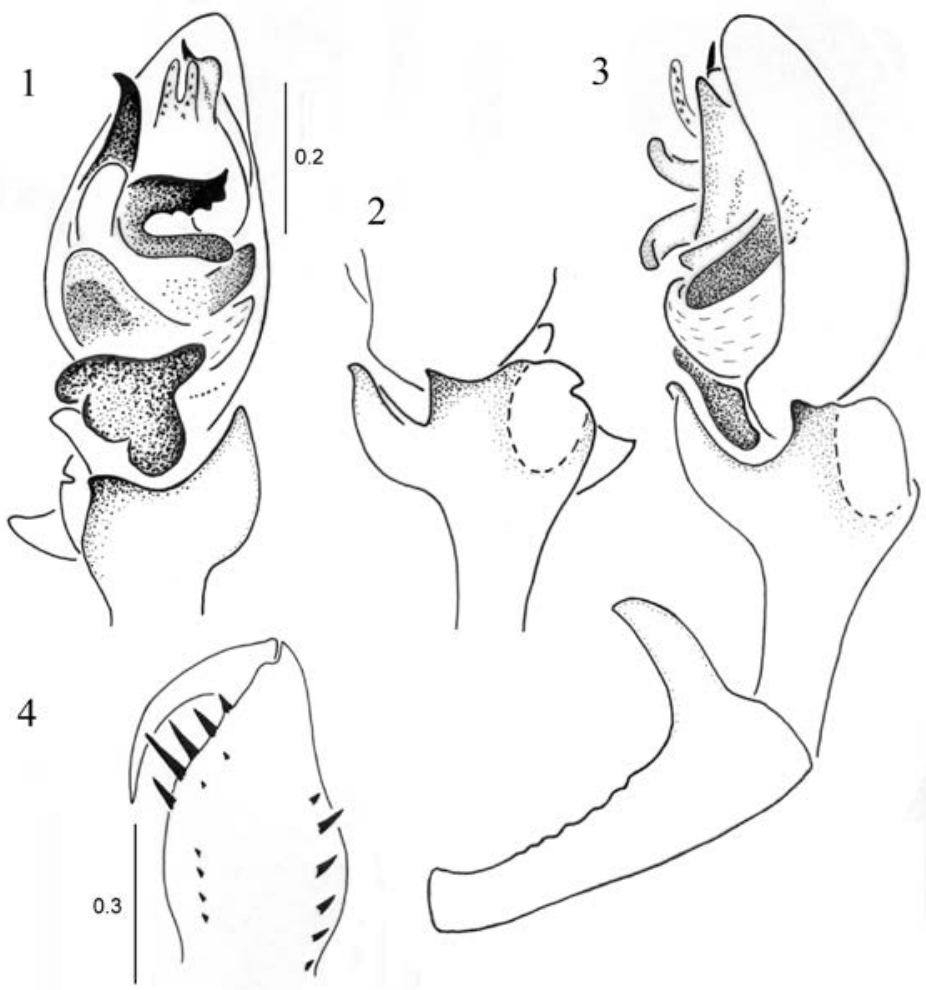

Figs 1-4. Male palp and the chelicera of Erigone cristatopalpus: 1 - palp, ventral view; 2 - palpal tibia, dorsal view; 3 - retrolateral view; 4 - cheliceral dentition.

Distribution: It is a very rare spider species, which distribution in the Central Europe is restricted to the highest mountain ranges, i.e. the Alps (Simon 1884, Thaler 1978, Muster \& Hänggi 2009, Tanasevitch 2011) and Slovakian part of the Tatra Mountains (Miller 1971, Svatoň \& Kovalčík 2006). The species has been found in Austria, France, Germany, Italy, Lichtenstein, Slovakia, Switzerland (van Helsdingen 2016). Lately, it was also reported in the Czech Republic, from the Hrubý Jeseník (Rủžička 2016). E. cristatopalpus is also known in other parts of the Palaearctic (mountains of South Siberia, East Siberia, Russian Far East) and in the Nearctic (Tanasevitch 2011, 2013). 

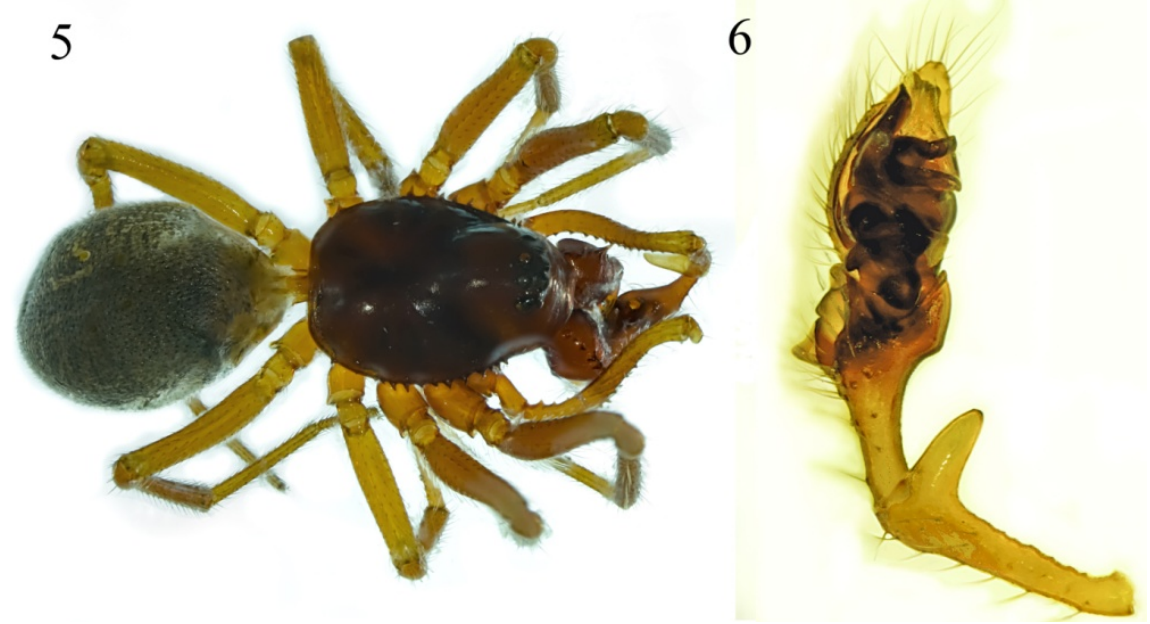

Figs 5-6. Erigone cristatopalpus: 5 - male habitus, 6 - male palp - ventral view.

Remarks: There used to be numerous taxonomical ambiguities within the Erigone psychrophila-group (to which the presented species belongs; Crosby \& Bishop 1928) and many old records might have been just a mistake (Muster \& Hänggi 2009, Tanasevitch 2011). The male of E. cristatopalpus has a very distinctive, large mesial and posterior tooth in the embolic division of the palp (Figs 1, 3,6) and small but clear dorsal apophysis on the palpal tibia, next to the very noticeable tibial pit (Figs 1, 2, 6).

Both of the collected E. cristatopalpus specimens have the cheliceral dentition as depicted in the Fig. 4, i.e. six anteriolateral teeth in total, the two terminal - very small, the four in between - conspicuous. This number may vary between four and six and it is variable within the species (Muster \& Hänggi 2009, Tanasevitch 2011). The two specimens were caught in the subalpine peat bog. This fact stays in accordance with the previous information that this species has a strong affinity to wet habitats (Muster \& Hänggi 2009).

\section{Panamomops sulcifrons (Wider, 1834)}

(Figs 7, 8)

Material: Izera Mts., Izera Valley by the stream Kobyła, 5050'11"N, 15²2'26"E, $835 \mathrm{~m}$ a.s.l., sweep net, 1 female, 9 May 2010; a transition mire on a mild slope, by the spruce forest.

Distribution: P. sulcifrons is widespread, but not a common species. Recording this spider in Poland was expected, as $P$. sulcifrons was known - among many others - from Germany, Slovakia and the Czech Republic (van Helsdingen 2016), including a few records from the Giant Mountains (Kůrka \& Szymkowiak 2007) and the Izera Mountains (Kůrka 1999).

Remarks: The female may be readily identified by the form of epigyne (Fig. 8).

Theridiidae

\section{Theridion boesenbergi (Strand, 1904)}

(Figs 9-11)

Material: Giant Mts., Szrenicki Kocioł, 5047'01"N, 15³1'52"E, 1310 m a.s.l., sweep net, 1 male, 13 Jun 2011; a subalpine transition mire, with other mountainous habitats, such as grasslands and dwarf mountain pine in the nearest vicinity. 
Distribution: The spider is known from many European countries, including the European part of Russia, but it was also found in Caucasus. The data on its distribution have already been summarized by Kůrka \& Vaněk (2010).

Remarks: A record of Th. boesenbergi from the foot of the Giant Mountains was given by Kůrka \& Vaněk (2010). They have reported a single female of this species in a spruce forest. Therefore, we present the second record of this species from the area and the first one from Poland. Theridion boesenbergi is considered as the species preferring trees, the records from spruce seem to be the most numerous, however it was also found in the other habitats (reviewed by Blick \& Goßner 2006, Lemke 2009, Kůrka \& Vaněk 2010). In the presented study it was recorded in the subalpine level of the mountains, where high trees do not grow. The locality is a part of a greater complex of miscellaneous mountainous habitats, including small transition mires, subalpine grasslands, dwarf mountain pine and just few singular, low spruce trees.
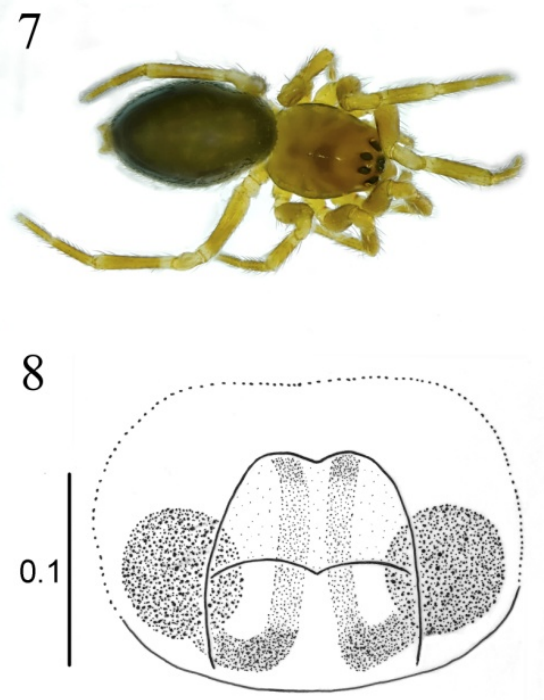

Figs 7-8. Panamomops sulcifrons: 7 - female habitus, 8 - epigyne
9

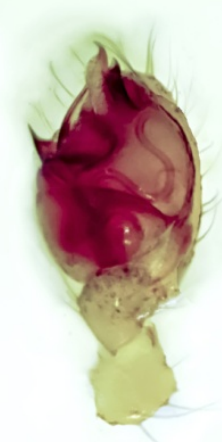

11

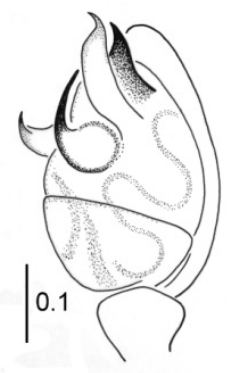

10

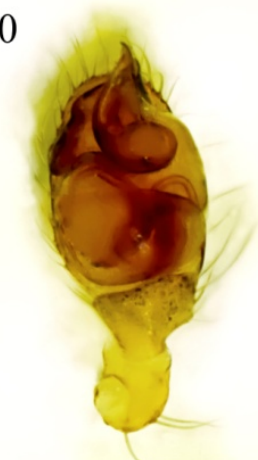

12

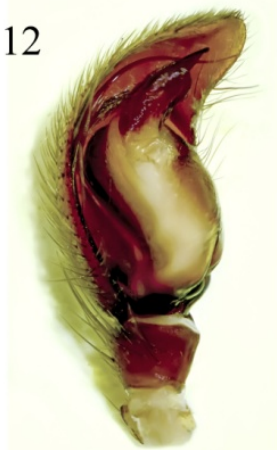

Figs 9-11. Male palp of Theridion boesenbergi: 9, 11. ventroretrolateral view, 10 - ventral view;

Fig. 12. Male palp of Gnaphosa lapponum, ventral view.

Gnaphosidae

\section{Gnaphosa lapponum L. Koch, 1866}

(Fig. 12)

Material: Giant Mts., Úpa peat bog and its surroundings, 5044'20"N, 15²4'28"E, 1430 m a.s.l., pitfall traps, 3 males, 4-26 Jul 2010, 24 Jul-13 Aug 2012, 1-22 Sep 2012; a subalpine mire composed of a mosaic of habitats, mainly raised parts of a bog and dwarf mountain pine; Nardus stricta grasslands surrounding the mire complex. 
Distribution: It is one of the species with a typical disjunctive, boreo-mountainous distribution (Růžička 2011). It has been recorded many times in the subalpine level of the Giant Mountains, however only on the Czech side of the border (Růžička \& Vaněk 1997, Kůrka \& Szymkowiak 2007, Materna et al. 2010, Růžička et al. 2012), hence it was not put on the national list of Polish spiders.

Remarks: Three males were recorded in the biggest subalpine mire on the plateau of the Giant Mountains and in the surrounding grasslands. Both of these habitats lay on the two sides of the national border, and the species was already recorded in these habitats by the above mentioned authors.

\section{DISCUSSION}

The presented records of the four species new to the fauna of Poland - one of which is also new for this part of the Sudetes - are based on a very small number of specimens, the records are nevertheless certain and worth mentioning. The majority of records that is given here comes from mires (i.e. peat bogs and poor fens), however one must bear in mind that the presented species not always are mire-specialists and sampling effort in different habitats of the mountains was decidedly uneven.

The most important information presented here is that Erigone cristatopalpus occurs in the Giant Mountains. It is a further example of a species found in the Central Europe only in the mountains. The considerable list of mountainous or boreo-mountainous taxa that live in the subalpine level of the Giant Mountains (Kůrka \& Szymkowiak 2007, Růžička et al. 2012) is therefore supplemented. The other species - although already known from the area - are rarely found and were expected in Poland considering their distribution in the neighbouring countries (Panamomops sulcifrons, Theridion boesenbergi), or their example shows some limitations of the national species lists (Gnaphosa lapponum).

\section{ACKNOWLEDGEMENTS}

The study was carried out with permissions of the Karkonosze National Park and the Regional Directorate for Environment Protection in Wrocław. We thank for the cooperation.

\section{REFERENCES}

BLICK T. \& GoßnER M. 2006. Spinnen aus Baumkronen-Klopfproben (Arachnida: Araneae), mit Anmerkungen zu Cinetata gradata (Linyphiidae) und Theridion boesenbergi (Theridiidae). Arachnologische Mitteilungen 31: 2339.

Crosby C.R. \& Bishop S.C. 1928. Revision of the spider genera Erigone, Eperigone and Catabrithorax (Erigoneae). New York State Museum Bulletin 278: 1-73.

HELSDINGEN P. VAN 2016. Fauna Europaea: Spiders. Fauna Europaea version 2.6.2. Available at http://www.faunaeur.org (01 August 2016).

Kupryjanowicz J. 2008. Pająki, Araneae. In: BogdAnOwiCZ W., ChudZICKA E., PilipiUK I. \& SKIBIŃSKA E. (eds), Fauna of Poland. Characteristics and checklist of species, pp. 223-239. Muzeum i Instytut Zoologii Polskiej Akademii Nauk, Warszawa, 603 pp.

KU゚RKA A. 1999. Pavouci (Araneida) Chráněné krajinné oblasti Jizerské hory. Sborník Severočeského Muzea, Př́ŕrodní Vědy 21: 119-136.

KU゚RKA A. \& SZYMKOWIAK P. 2007. Pavouci. In: ŠMATLÁK J. \& ZYKÁNOVÁ J. (eds), Krkonoše - př́roda, historie, život, pp. 235-240. Praha, Baset, 864 pp.

KŮRKA A. \& VANĚK J. 2010. Nález dvou vzácných druhů pavouků (Araneae) Cinetata gradata (Simon, 1881) (Linyphiidae) a Theridion boesenbergi Strand, 1904 (Theridiidae) v podhůří Krkonoš. Opera Corcontica 47: 275280.

LEMKE M. 2009. Nachweis fünf neuer Webspinnenarten (Araneae) für Schleswig-Holstein und Anmerkungen zu seltenen Arten in Niedersachsen. Arachnologische Mitteilungen 38: 28-32. 
MATERNA J., VANĚK J., KŮRKA A. \& VONIČKA P. 2010. Epigeičtí pavouci (Araneae), sekáči (Opiliones) a střevlíci (Coleoptera: Carabidae) vybraných rostlinných společenstev krkonošské a skandinávské tundry. Opera Corcontica 47: 187-209.

MiLleR F. 1971. Pavouci - Araneida. Klíč zvířeny ČSSR. In: DANIEL M. \& ČERNÝ V. (eds), Klíč zvířeny ČSSR IV, pp. 51-306. Akademie ved Ćeske republiky, Praha, 603 pp.

Muster C. \& HÄNGGI A. 2009. The Erigone psychrophila group in the Alps (Araneae: Linyphiidae). Contributions to Natural History 12: 987-1005.

ROZWAŁKA R. \& STAŃSKA M. 2008. Check-list of spiders (Araneae) of Poland. Available at http://www.arachnologia.edu.pl/gatunki/7-pajaki-polski.html (10 August 2016).

RŮŽIČKA V. 2011. Central European habitats inhabited by spiders with disjunctive distributions. Polish Journal of Ecology 59: 367-380.

RŮŽIČKA V. 2016. Erigone cristatopalpus Simon, 1884. Pavouk 41: 5-7.

RŮŽıČKA V. \& VANĚK J. 1997. Pavouci (Araneae) Úpské rašeliny a Studniční hory. Opera Corcontica 34: $179-187$.

RŮŽIČKA V., VANĚK J. \& ŠMILAUER P. 2012. Spiders in mountain habitats of the Giant Mountains. Russian Journal of Ecology 43: 341-347.

SIMON E. 1884. Les arachnides de France 5. 180-885.

SVATOŇ J. \& KovALČ́́K R. 2006. Present state of knowledge of the araneo-fauna in the Tatras National Park. Oecologia Montana 15: 1-14.

SZYMKOWIAK P. 2004. Maro sublestus Falconer, 1915 (Araneae, Linyphiidae) - a spider new to the fauna of Poland. Fragmenta Faunistica Musei Zoologici Polonici 47: 139-142.

TANASEVITCH A.V. 2011. On linyphiid spiders (Araneae) from the Eastern and Central Mediterranean kept at the Muséum d'histoire naturelle, Geneva. Revue Suisse de Zoologie 118: 49-91.

TANASEVITCH A.V. 2013. The linyphiid spiders of the Altais, Southern Siberia (Aranei: Linyphiidae). Arthropoda Selecta 22: 267-306.

THALER K. 1978. Über wenig bekannte Zwergspinnen aus den Alpen - V (Arachnida: Aranei, Erigonidae). Beiträge zur Entomologie 28: 183-200.

TOMASIEWICZ B. \& WOŹNY M. 2004. Przegląd fauny pająków (Araneae) polskich Karkonoszy. Przyroda Sudetów 7: 109-118.

WiŚNIEWSKI K. \& WESOŁOWSKA W. 2012. Maro lepidus Casemir, 1961, a newly recorded spider species (Araneae, Linyphiidae) for Poland. Fragmenta Faunistica 55: 155-160.

WiŚNIEWSKI K., RozWAŁKA R. \& WESOŁOWSKA W. 2013. The first record of Hahnia difficilis Harm, 1966 (Araneae, Hahniidae) in Poland. Fragmenta Faunistica 56: 55-63.

WiŚNIEWSKI K. \& WESOŁOWSKA W. 2015. Maro lehtineni (Araneae: Linyphiidae) - a spider species new to the fauna of Poland. Arachnologische Mitteilungen 50: 81-84.

Woźny M., CZAJKA M., PIlAWSKi S. \& BednARZ S. 1988. Pająki (Aranei) polskich Sudetów. Acta Universitatis Wratislaviensis 972. Prace Zoologiczne 19: 53-130.

\section{STRESZCZENIE}

\section{[Rzadkie gatunki pająków z Karkonoszy i Gór Izerskich - nowe stwierdzenia dla fauny Polski]}

W pracy tej zaprezentowano dane na temat czterech gatunków pająków nowych dla fauny Polski. Zostały one znalezione na torfowiskach lub w środowiskach $\mathrm{z}$ nimi sąsiadujących w Karkonoszach i Górach Izerskich. Niektóre z tych środowisk leżą na granicy polskoczeskiej. Stwierdzone gatunki to: Erigone cristatopalpus Simon, 1884, Panamomops sulcifrons (Wider, 1834), Theridion boesenbergi Strand, 1904, Gnaphosa lapponum (L. Koch, 1866); wszystkie z nich są rzadko odnotowywane. Erigone cristatopalpus w Europie środkowej jest znany tylko z wysokich pasm górskich, nie był on dotąd podawany w Karkonoszach i Górach Izerskich. Pozostałych trzech gatunków można było spodziewać się na obszarze Polski, ponieważ zostały one zaobserwowane już w tych pasmach górskich po czeskiej stronie granicy. 